\title{
Comparative Evaluation of the Antidiabetic Effects of Different Parts of Cassia fistula Linn, a Southeast Asian Plant
}

\author{
John Wilking Einstein, Mustafa Mohd Rais, and Mustafa Ali Mohd \\ Department of Pharmacology, Faculty of Medicine, University of Malaya, 50603 Kuala Lumpur, Malaysia \\ Correspondence should be addressed to John Wilking Einstein; johnwilkin@gmail.com
}

Received 11 May 2012; Accepted 21 June 2012

Academic Editor: Patricia Valentao

Copyright ( 2013 John Wilking Einstein et al. This is an open access article distributed under the Creative Commons Attribution License, which permits unrestricted use, distribution, and reproduction in any medium, provided the original work is properly cited.

\begin{abstract}
The hypoglycemic effect of the methanolic and aqueous extracts of whole parts of Cassia fistula in both normoglycemic and streptozotocin-nictotinamide induced Type 2 diabetic rats were investigated. Acute toxicity, oral glucose tolerance test and glucose uptake in isolated rat hemidiaphragm were performed in normal rats. Diabetes was induced in Sprague Dawley rats by the administration of streptozotocin-nictotinamide $(50,110 \mathrm{mg} / \mathrm{kg}$ b.w., resp.) intraperitoneally. Different extracts of Cassia was administered to diabetic rats at 250 and $500 \mathrm{mg} / \mathrm{kg}$ doses for 21 days. Biochemical parameters like blood glucose, insulin, glycosylated hemoglobin, lipid profile, and serum marker enzymes were determined. The methanolic extract of the bark and leaves were show more effective in causing hypoglycemia in normoglycemic rats. Diabetic rats showed increased levels of glycosylated hemoglobin, reduced levels of plasma insulin, were significantly reverted to near normal after oral administration of the bark and leaf methanolic extracts. Glucose uptake studies in isolated rat hemidiaphragm have shown enhanced peripheral utilization of glucose. Chronic treatment of Cassia remarkably restored the normal status of the histopathological changes observed in the selected tissues. Dose dependent anti-diabetic effects with the cohorts receiving the methanolic extract of bark followed by leaves of Cassia was revealed.
\end{abstract}

\section{Introduction}

Diabetes mellitus (DM), caused by inherited and/or acquired deficiency or inadequate secretion of hormone insulin (type I or insulin-dependent diabetes mellitus (IDDM)) or due to a an inadequate response of target cells to insulin (type II or noninsulin-dependent diabetes mellitus (NIDDM)), or by a combination of these factors culminating in hyperglycemia is, a disease as old as mankind [1]. Recent reports indicate DM is today the world's leading endocrine disorder, constituting approximately six percent of the population, of which 90 percent is type II DM [1]. The currently available therapeutic options, such as oral hypoglycemics and insulin, are not always satisfactory in maintaining euglycemia and in avoiding late stage DM complications. Additionally, the chronic nature of the disease and the associated complications require regular treatment and incur huge financial expenditure on the family and the healthcare system. Therefore, a need for alternative drugs that are effective, inexpensive, affordable, and safe to consume is being recognized.

One of the best approaches in identifying novel antidiabetic agents is to scientifically investigate the efficacy of medicinal plants recognized to be effective in the various traditional system of medicine [2]. Cassia fistula Linn commonly known as "golden shower" and belonging to Leguminosae family is one such plant reported to be effective as an antidiabetic agent in the various folk systems of medicine [3]. The plants are fast growing small tree or tall shrubs and are found growing throughout tropical countries of the world, from West Indies to South Asia (India, Thiland, Malaysia, Brunei Darussalam, Indonesia, Vietnam, and Philippines) and from South Africa to Egypt [4]. Almost all parts of the plants are of medicinal use in the various folk system of medicine in Southeast Asia, and scientific studies have validated many of the ethnomedicinal observations. Preclinical studies have shown that the extract of flowers, leaves, 
TABLE 1: Phytochemical studies of Cassia fistula extracts.

\begin{tabular}{|c|c|c|c|c|c|c|c|c|}
\hline Extracts & Gly & Alk & Fla & Phe & Sap & Tan & Ste & Res \\
\hline Bark methanol & - ve & +ve & $-\mathrm{ve}$ & $+\mathrm{ve}$ & - ve & $+\mathrm{ve}$ & $+\mathrm{ve}$ & $-\mathrm{ve}$ \\
\hline eous & - ve & + ve & - ve & $+\mathrm{ve}$ & $-\mathrm{ve}$ & $+v e$ & $+\mathrm{ve}$ & $-\mathrm{ve}$ \\
\hline Leaf & + ve & -ve & $+\mathrm{ve}$ & $-\mathrm{ve}$ & $-\mathrm{ve}$ & $-\mathrm{ve}$ & $-\mathrm{ve}$ & - ve \\
\hline Leaf a & + ve & - ve & + ve & - ve & $-\mathrm{ve}$ & - ve & -ve & - ve \\
\hline thanol & + ve & $+\mathrm{ve}$ & + ve & $+\mathrm{ve}$ & $-\mathrm{ve}$ & $-\mathrm{ve}$ & $-\mathrm{ve}$ & - ve \\
\hline Flow & + ve & + ve & + ve & + ve & $-\mathrm{ve}$ & - ve & - ve & - ve \\
\hline Pod $r$ & +ve & +ve & - ve & + ve & + ve & $-v e$ & $-\mathrm{ve}$ & + ve \\
\hline Pod aqueous & +ve & $+\mathrm{ve}$ & - ve & +ve & $+\mathrm{ve}$ & $-\mathrm{ve}$ & $-\mathrm{ve}$ & +ve \\
\hline
\end{tabular}

Gly: glycoside; Alk: alkaloid; Fla: flavonoid; Phe: phenol; Sap: saponin; Tan: tannin; Ste: steroid; Res: resin.

+ve: present; -ve: absent.

bark, and pods, namely the ether extract of leaves possess antibacterial activity against $S$. aureus and S. album [5]. Seeds of $C F$ are reported to have antibacterial [6], antitumour [7], and antifertility effect [8] and four novel compounds has been isolated [9]. The antioxidant effect of the crude extracts of stem bark, leaves, flowers, and fruit pulp of $C$. fistula has been assessed [10]. Though the hypoglycemic efficacy of leaves and seeds of $C F$ have been studied [11]. The methanol extract of the stem of $C F$ and catechins isolated from the extract are shown to reduce the blood glucose levels in STZ-induced DM rats [3]. Recently in milieu of these observations and to validate the ethnomedical observations, for the first time the present study was undertaken to evaluate the hypoglycemic effects of the various parts of Cassia fistula (leaves, barks, flowers, and pods) and extracts (aqueous and methanolic) in both normal (nondiabetic) and type II DM rats (induced by STZ-nictotinamide).

\section{Materials and Methods}

2.1. Plant Material. The leaves, barks, flowers, and pods of Cassia fistula were together collected in 2007 and around Bangalore district, India, in April and authenticated by botanist, Dr. V. C. Subbanna, Gandhi Krishi Vignana Kendra, Bangalore, India.

2.2. Preparation of Plant Extracts. The plant materials were shade dried and pulverized in mechanical mill. The appropriate dried powdered plant materials $(1 \mathrm{~kg})$ were successively extracted with $n$-hexane, chloroform, and methanol (all solvents were HPLC grade) by soxhlet apparatus and with double distilled water $(500 \mathrm{~mL}$ each) by reflux. The extracts were evaporated to dryness with a rotary evaporator, under reduced pressure at $40^{\circ} \mathrm{C}$. The extracts are as follows: bark methanol extract (BME), bark aqueous extract (BAE), leaf methanol extract (LME), leaf aqueous extract (LAE), flower methanol extract (FME), flower aqueous extract (FAE), pods methanolic extract (PME), and pods aqueous extract (PAE). The extracts were stored at $4^{\circ} \mathrm{C}$ and used for further investigation.

2.3. Chemicals. Glucose and other biochemical parameters kits were obtained from Randox Laboratories Ltd. (Co.
Antrim, UK). STZ and nicotinamide were purchased from Sigma Chemicals Co. (St. Louis, MO, USA). Standard drug glibenclamide $(1.0 \mathrm{mg} / \mathrm{kg}$. b.wt) pure samples were procured from Biocon Pvt. Ltd., Bangalore, India. The drugs and reagents were reconstituted in sterile double distilled water.

2.4. Animals. The study was conducted on Sprague Dawley (SD) rats, five to six weeks of age, weighing 200-250 g, which were housed in colony cages (three rats per cage) at an ambient temperature of $25 \pm 2^{\circ} \mathrm{C}$ with $12 \mathrm{~h}$ light and $12 \mathrm{~h}$ dark cycle. The rats were fed standard diets and water ad libitum. The animals were allowed to acclimatize to the laboratory environment for 1 week. All procedures complied with the standards for the care and use of animal subjects as stated in the guidelines laid by Institutional Animal Ethical Committee (IAEC), University of Malaya, Kuala Lumpur (FAR/07/12/2007/MRM(R).

2.5. Acute Toxicity Study. The acute oral toxicity study was carried out in accordance to the guidelines set by the Organisation for Economic Co-operation and Development (OECD) 423 [12]. Sprague Dawley rats were fasted for overnight and administered range of concentration (50 to $5000 \mathrm{mgkg}^{-1}$ ) of the methanolic and aqueous extracts. The animals were observed continuously for the first two hours, followed by once every hour up to $6 \mathrm{~h}$ for any changes in behavioral, neurological, and autonomic profiles and after 24 and $72 \mathrm{~h}$ to identify lethality.

2.6. Effect of CF Extract on Serum Glucose Levels of Normal Fasted Rats. The fasting blood sugar level of each animal was determined after overnight fasting for $18 \mathrm{~h}$. Normoglycemic rats were divided into eighteen experimental groups $(n=$ 6 per group). The first group of animals was given saline through oral intubation and served as control. Group II was given glibenclamide $\left(2.5 \mathrm{mgkg}^{-1}\right)$, taken as standard. Group III-XVIII was given an aqueous and methanolic suspension of $C F$ extracts (leaf, flower, bark, and pods) orally at a dose of 250 and $500 \mathrm{mgkg}^{-1}$, respectively. The blood samples were collected from the tail vein just prior to and at 1,2, 4, and $8 \mathrm{~h}$ after the extract. Serum glucose was measured by GOD/POD enzymatic method [13].

\subsection{Determination of the Oral Glucose Tolerance Test (OGTT)} in Normal Rats. OGTT experiment was performed as explained by Bonner-Weir [14]. The normal rats were divided into 18 groups $(n=6)$ and were fasted overnight $(18 \mathrm{~h})$. The next day the rats were administered either drinking water or glibenclamide ( $2.5 \mathrm{mgkg}^{-1}$ used as the standard drug) or 250 and $500 \mathrm{mgkg}^{-1}$ of the extracts. Glucose $\left(2 \mathrm{gkg}^{-1}\right)$ was administered $30 \mathrm{~min}$ after the feeding of the extract. Blood was withdrawn from the tail vein under ether inhalation anesthesia at $240 \mathrm{~min}$ of glucose administration and estimated using biochemical kits in a semiautoanalyser STAT FAX 3300. 
TABLE 2: Effect of oral administration of methanolic and aqueous extracts of Cassia fistula Linn bark, leaves, flower, and pods on blood glucose concentration in normal rats.

\begin{tabular}{|c|c|c|c|c|c|}
\hline \multirow{2}{*}{ Experimental group } & \multicolumn{5}{|c|}{ Blood glucose concentration (mg/dL) } \\
\hline & $0 \mathrm{~h}$ & $1 \mathrm{~h}$ & $2 \mathrm{~h}$ & $4 \mathrm{~h}$ & $8 \mathrm{~h}$ \\
\hline Normal control & $85.3 \pm 2.4$ & $84.0 \pm 2.4$ & $86.3 \pm 2.1$ & $82.3 \pm 3.5$ & $79.8 \pm 3.4$ \\
\hline Glibenclamide ( $2.5 \mathrm{mg} / \mathrm{kg})$ & $87.3 \pm 2.6$ & $79.7 \pm 3.4$ & $70.2 \pm 1.4^{\mathrm{c}}$ & $61.0 \pm 3.1^{\mathrm{c}}$ & $56.0 \pm 2.0^{\mathrm{c}}$ \\
\hline BME $250 \mathrm{mg} / \mathrm{kg}$ & $85.7 \pm 3.2$ & $84.5 \pm 2.4$ & $80.8 \pm 3.4$ & $76.3 \pm 1.7$ & $70.3 \pm 3.3$ \\
\hline BAE $250 \mathrm{mg} / \mathrm{kg}$ & $85.3 \pm 2.6$ & $82.0 \pm 2.0$ & $80.0 \pm 2.4$ & $76.7 \pm 2.8$ & $71.0 \pm 3.1$ \\
\hline BME $500 \mathrm{mg} / \mathrm{kg}$ & $86.7 \pm 2.7$ & $80.0 \pm 3.0$ & $73.7 \pm 3.9^{\mathrm{a}}$ & $68.0 \pm 1.5^{\mathrm{b}}$ & $62.3 \pm 2.1^{\mathrm{b}}$ \\
\hline BAE $500 \mathrm{mg} / \mathrm{kg}$ & $87.8 \pm 2.8$ & $84.8 \pm 3.7$ & $81.0 \pm 3.2$ & $76.5 \pm 3.2$ & $70.7 \pm 2.5$ \\
\hline LME $250 \mathrm{mg} / \mathrm{kg}$ & $81.3 \pm 1.7$ & $80.0 \pm 3.0$ & $78.3 \pm 2.7$ & $75.0 \pm 2.8$ & $70.5 \pm 3.9$ \\
\hline LAE $250 \mathrm{mg} / \mathrm{kg}$ & $82.3 \pm 3.3$ & $80.3 \pm 3.3$ & $78.7 \pm 3.1$ & $75.5 \pm 1.9$ & $71.7 \pm 2.4$ \\
\hline LME $500 \mathrm{mg} / \mathrm{kg}$ & $84.1 \pm 2.5$ & $80.0 \pm 3.0$ & $76.2 \pm 3.4$ & $71.5 \pm 3.1^{\mathrm{a}}$ & $65.3 \pm 2.0^{\mathrm{b}}$ \\
\hline LAE 500 mg/kg & $86.0 \pm 3.6$ & $83.3 \pm 2.5$ & $81.5 \pm 2.6$ & $76.3 \pm 2.7$ & $70.2 \pm 3.2$ \\
\hline FME $250 \mathrm{mg} / \mathrm{kg}$ & $87.1 \pm 2.7$ & $84.7 \pm 3.4$ & $82.0 \pm 2.0$ & $75.8 \pm 2.5$ & $71.3 \pm 2.4$ \\
\hline FAE $250 \mathrm{mg} / \mathrm{kg}$ & $82.5 \pm 2.8$ & $83.3 \pm 2.7$ & $79.2 \pm 2.1$ & $76.2 \pm 1.2$ & $70.2 \pm 2.2$ \\
\hline FME $500 \mathrm{mg} / \mathrm{kg}$ & $80.0 \pm 1.5$ & $79.2 \pm 2.7$ & $78.4 \pm 4.8$ & $74.7 \pm 2.1$ & $73.5 \pm 2.7$ \\
\hline FAE $500 \mathrm{mg} / \mathrm{kg}$ & $86.2 \pm 2.5$ & $84.8 \pm 3.8$ & $83.3 \pm 3.5$ & $79.0 \pm 3.2$ & $74.0 \pm 2.7$ \\
\hline PME $250 \mathrm{mg} / \mathrm{kg}$ & $85.8 \pm 3.5$ & $83.3 \pm 1.1$ & $83.7 \pm 1.8$ & $80.3 \pm 3.3$ & $85.7 \pm 3.2$ \\
\hline PAE $250 \mathrm{mg} / \mathrm{kg}$ & $84.0 \pm 2.7$ & $83.3 \pm 3.3$ & $82.9 \pm 3.2$ & $79.0 \pm 2.1$ & $85.7 \pm 3.2$ \\
\hline PME 500 mg/kg & $83.3 \pm 2.7$ & $80.2 \pm 3.4$ & $79.3 \pm 1.9$ & $76.0 \pm 2.7$ & $85.7 \pm 3.2$ \\
\hline PAE $500 \mathrm{mg} / \mathrm{kg}$ & $82.0 \pm 2.5$ & $80.3 \pm 1.3$ & $78.3 \pm 2.6$ & $76.3 \pm 2.2$ & $85.7 \pm 3.2$ \\
\hline
\end{tabular}

Values are mean $\pm \operatorname{SEM}(n=6) . P$ value: ${ }^{\mathrm{a}}<0.05,{ }^{\mathrm{b}}<0.01,{ }^{\mathrm{c}}<0.001$ as compared with normal control group (by one-way ANOVA followed by Dunnett's multiple comparison test).

TABLE 3: Effect of repeated administration of methanolic and aqueous extracts of bark, leaf, and flower of Cassia fistula on glucose level in STZ-nicotinamide induced diabetic animals.

\begin{tabular}{|c|c|c|c|c|c|}
\hline \multirow{3}{*}{ Experimental group } & \multicolumn{5}{|c|}{ Blood glucose concentration (mg/dL) } \\
\hline & \multirow{2}{*}{ Initial concentration } & \multicolumn{4}{|c|}{ Diabetic rats } \\
\hline & & 0 & 7 & 14 & 21 \\
\hline Normal control & $76.58 \pm 1.5$ & $75.26 \pm 1.82$ & $74.43 \pm 1.74$ & $76.59 \pm 1.8$ & $77.46 \pm 1.74$ \\
\hline Diabetic control & $84.5 \pm 1.8$ & $216.3 \pm 3.7$ & $218.4 \pm 4.20$ & $214.5 \pm 4.20$ & $218.2 \pm 6.21$ \\
\hline Glibenclamide & $80.4 \pm 2.6$ & $213.7 \pm 4.1$ & $175.5 \pm 5.05^{\mathrm{b}}$ & $155.5 \pm 5.04^{\mathrm{c}}$ & $146.1 \pm 5.71^{\mathrm{C}}$ \\
\hline $\mathrm{BME} 250 \mathrm{mg} / \mathrm{kg}$ & $76.7 \pm 2.3$ & $216 \pm 3.8$ & $200.6 \pm 4.51$ & $186.6 \pm 4.64^{\mathrm{b}}$ & $185.7 \pm 4.64^{\mathrm{b}}$ \\
\hline BAE $250 \mathrm{mg} / \mathrm{kg}$ & $77.5 \pm 1.8$ & $213 \pm 4.0$ & $208.7 \pm 4.29$ & $199.5 \pm 4.34$ & $191.5 \pm 4.26^{\mathrm{a}}$ \\
\hline BME $500 \mathrm{mg} / \mathrm{kg}$ & $76.9 \pm 1.6$ & $213.2 \pm 4.2$ & $193.8 \pm 3.90^{\mathrm{a}}$ & $169.4 \pm 3.89^{c}$ & $158.9 \pm 3.89^{\mathrm{C}}$ \\
\hline BAE $500 \mathrm{mg} / \mathrm{kg}$ & $82.8 \pm 3.4$ & $214.5 \pm 4.1$ & $205.7 \pm 6.06$ & $190.8 \pm 5.83^{\mathrm{b}}$ & $189.7 \pm 5.79^{\mathrm{a}}$ \\
\hline LME $250 \mathrm{mg} / \mathrm{kg}$ & $77.7 \pm 3.1$ & $213.7 \pm 3.1$ & $207.9 \pm 8.60$ & $194.7 \pm 4.64^{\mathrm{a}}$ & $189.7 \pm 4.65^{\mathrm{a}}$ \\
\hline LAE $250 \mathrm{mg} / \mathrm{kg}$ & $76.6 \pm 2.3$ & $214.2 \pm 4.9$ & $212.1 \pm 5.13$ & $198.5 \pm 4.66$ & $190.6 \pm 4.65^{\mathrm{a}}$ \\
\hline LME $500 \mathrm{mg} / \mathrm{kg}$ & $75.6 \pm 3.2$ & $217.8 \pm 3.0$ & $198.5 \pm 5.71$ & $177.6 \pm 5.69^{c}$ & $168.6 \pm 5.68^{\mathrm{c}}$ \\
\hline LAE 500 mg/kg & $77.9 \pm 1.2$ & $215.3 \pm 4.5$ & $209.4 \pm 4.07$ & $201 \pm 3.52$ & $194.9 \pm 3.61$ \\
\hline $\mathrm{FME} 250 \mathrm{mg} / \mathrm{kg}$ & $84.2 \pm 2.6$ & $212 \pm 3.0$ & $213.1 \pm 8.62$ & $204.2 \pm 5.01$ & $196.2 \pm 5.01$ \\
\hline FAE $250 \mathrm{mg} / \mathrm{kg}$ & $79.2 \pm 2.2$ & $210.5 \pm 5.0$ & $214 \pm 10.11$ & $205.2 \pm 4.61$ & $197.7 \pm 6.07$ \\
\hline FME 500 mg/kg & $78.4 \pm 2.6$ & $219.8 \pm 3.8$ & $208.5 \pm 4.94$ & $198.4 \pm 4.98$ & $191.4 \pm 4.97$ \\
\hline FAE $500 \mathrm{mg} / \mathrm{kg}$ & $81.8 \pm 2.6$ & $221.3 \pm 0.7$ & $210.9 \pm 4.92$ & $204.9 \pm 5.05$ & $197.8 \pm 5.05$ \\
\hline
\end{tabular}

Values are mean $\pm \operatorname{SEM}(n=6)$.

$P$ value: ${ }^{\mathrm{a}}<0.05,{ }^{\mathrm{b}}<0.01,{ }^{\mathrm{c}}<0.001$ as compared with diabetic control group (by one-way ANOVA followed by Dunnett's multiple comparison test).

\subsection{Evaluation C. fistula Extracts on Various Parameters in Type II DM Rats}

2.8.1. Induction of NIDDM. The rats were fasted overnight and were administered freshly prepared STZ solution $(50 \mathrm{mg} / \mathrm{kg}$ body weight dissolved in cold citrate buffer, $\mathrm{pH}$ 4.5) intraperitoneally (i.p.). Fifteen minutes after the i.p. administration, STZ, $110 \mathrm{mgkg}^{-1}$ body weight of nictotinamide (dissolved in saline) was given to the same rats by i.p. DM was identified by polydipsia, polyuria, and by measuring nonfasting plasma glucose levels. Animals with postprandial glycemia over $200-250 \mathrm{mgkg}^{-1}, 7$ days after STZ administration, were considered diabetic. Whole blood was collected from the tail vein of the rats. Control rats 
TABLE 4: Effect of methanolic and aqueous bark, leaf, and flower extracts of Cassia fistula on serum insulin and glycosylated hemoglobin (whole blood) in diabetic rats.

\begin{tabular}{lcc}
\hline Experimental group & Insulin (IU/mL) & $\begin{array}{c}\text { Glycosylated } \\
\text { hemoglobin }(\%)\end{array}$ \\
\hline Normal control & $130.5 \pm 3.6$ & $3.1 \pm 0.1$ \\
Diabetic control & $90.5 \pm 2.1$ & $9.0 \pm 0.2$ \\
Glibenclamide & $118.2 \pm 3.6^{\mathrm{c}}$ & $4.8 \pm 0.2^{\mathrm{c}}$ \\
BME $250 \mathrm{mg} / \mathrm{kg}$ & $103.5 \pm 4.6$ & $8.0 \pm 0.2^{\mathrm{b}}$ \\
BAE $250 \mathrm{mg} / \mathrm{kg}$ & $98.3 \pm 3.4$ & $8.4 \pm 0.2^{\mathrm{c}}$ \\
BME $500 \mathrm{mg} / \mathrm{kg}$ & $116.8 \pm 3.4^{\mathrm{c}}$ & $5.3 \pm 0.1^{\mathrm{c}}$ \\
BAE $500 \mathrm{mg} / \mathrm{kg}$ & $100.7 \pm 2.9$ & $8.1 \pm 0.2^{\mathrm{a}}$ \\
LME $250 \mathrm{mg} / \mathrm{kg}$ & $104.8 \pm 3.5^{\mathrm{a}}$ & $8.1 \pm 0.2^{\mathrm{a}}$ \\
LAE $250 \mathrm{mg} / \mathrm{kg}$ & $98.2 \pm 3.5$ & $8.5 \pm 0.3$ \\
LME $500 \mathrm{mg} / \mathrm{kg}$ & $114.5 \pm 2.0^{\mathrm{c}}$ & $5.9 \pm 0.2^{\mathrm{c}}$ \\
LAE $500 \mathrm{mg} / \mathrm{kg}$ & $99.3 \pm 2.9$ & $8.3 \pm 0.1$ \\
FME $250 \mathrm{mg} / \mathrm{kg}$ & $98.5 \pm 4.7$ & $8.4 \pm 0.2$ \\
FAE $250 \mathrm{mg} / \mathrm{kg}$ & $93.3 \pm 2.8$ & $8.5 \pm 0.3$ \\
FME $500 \mathrm{mg} / \mathrm{kg}$ & $103.2 \pm 3.0$ & $8.3 \pm 0.1$ \\
FAE $500 \mathrm{mg} / \mathrm{kg}$ & $95.8 \pm 4.6$ & $8.4 \pm 0.2$ \\
\hline
\end{tabular}

Values are mean $\pm \operatorname{SEM}(n=6)$.

$P$ value: ${ }^{\mathrm{a}}<0.05,{ }^{\mathrm{b}}<0.01,{ }^{\mathrm{c}}<0.001$ as compared with diabetic control group (by one-way ANOVA followed by Dunnett's multiple comparison test).

received only buffer. Animals, which did not develop more than $200 \mathrm{mgdL}^{-1}$ glucose levels, were rejected $[15,16]$.

2.8.2. Experimental Design and Treatment Schedule. The effect of the extracts was studied in STZ-nictotinamide induced diabetic rats or 21 days. The rats ( $n=7$ per group) were divided into 15 groups: group 1: normal rats treated with vehicle alone; group 2: diabetic control treated with STZ solution $\left(50 \mathrm{mgkg}^{-1}\right.$ body weight dissolved in cold citrate buffer, $\mathrm{pH} 4.5$ ) intraperitoneally (i.p.) $+110 \mathrm{mg} / \mathrm{kg}$ body weight of nictotinamide, i.p. (dissolved in saline); group 3: diabetic rats treated p.o. (oral route) with glibenclamide (Biocon. Pvt. Ltd., India); group 4 and 5 diabetic rats were administered $250 \mathrm{mgkg}^{-1}$ of Bark methanolic and aqueous extracts respectively; groups 6 and 7 diabetic rats were administered $500 \mathrm{mgkg}^{-1}$ of bark methanolic and aqueous extracts, respectively; groups 8 and 9 diabetic rats were administered $250 \mathrm{mgkg}^{-1}$ of leaf methanolic and aqueous extracts, respectively; groups 10 and 11 diabetic rats were administered $500 \mathrm{mg} / \mathrm{kg}$ of leaf methanolic and aqueous extracts, respectively; groups 12 and 13 diabetic rats were administered $250 \mathrm{mgkg}^{-1}$ of flower methanolic and aqueous extracts, respectively; groups 14 and 15 diabetic rats were administered $500 \mathrm{mgkg}^{-1}$ of flower methanolic and aqueous extracts, respectively. The saline, standard drug, and extracts were administered p.o. to respective groups for 21 days.

Blood samples were collected from the tail vein at 0,7 th, 14th, and 21st days and quantified for the blood glucose levels. On day 21, the fasted animals were euthanized under overdose of ketamine. The blood was collected by cardiac puncture and processed for estimating the levels of glycosylated hemoglobin (HbA1c) by ion exchange chromatography [17] and insulin by ELISA assay [18]. The serum was separated by centrifugation and analyzed for serum biochemical parameters, that is, aspartate transaminase (AST), alanine transaminase (ALT), alkaline phosphatase (ALP), total cholesterol (TC), triglycerides (TG), high density lipoprotein (HDL), and non-HDL using biochemical kits in a semiautoanalyser-STAT FAX 3300.

2.8.3. Total Protein Content. The protein contents of $10 \%$ liver homogenates were determined by using Lowry's method [19].

2.8.4. Lipid Peroxidation. Thiobarbituric acid reactive substances (TBARS) in homogenate were estimated by using standard method [20]. Briefly, $500 \mu \mathrm{L}$ of sample $(10 \%$ liver homogenate) was incubated with $300 \mu \mathrm{L}$ of $15 \%$ trichloroacetic acid (TCA), $300 \mu \mathrm{L}$ of $0.375 \%$ thiobarbituric acid (TBA), and $300 \mu \mathrm{L}$ of $5 \mathrm{~N}$ hydrochloric acid $(\mathrm{HCl})$ at $95^{\circ} \mathrm{C}$ for $15 \mathrm{~min}$; the mixture was cooled and centrifuged and the absorbance of the supernatant was measured at $532 \mathrm{~nm}$ against appropriate blank. The amount of lipid peroxidation was determined by using $1=1.56 \times 10^{5} \mathrm{M}^{-1} \mathrm{~cm}^{-1}$ and expressed as $\mathrm{nM}$ of (malonaldehyde) $\mathrm{MDA} / \mathrm{mg}$ of protein [21].

2.8.5. Histopathological Studies. At the end of the experimental period, the animals were sacrificed by cervical dislocation. The pancreas samples fixed for $48 \mathrm{~h}$ in $10 \%$ formalin saline were dehydrated by passing successfully in different mixture of ethyl alcohol-water, cleaned in xylene, and embedded in paraffin. Sections of pancreas were prepared and, then, stained with hematoxylin and eosin dye (H\&E), which mounted in neutral deparaffinated xylene (DPX) medium for microscopic observation.

2.9. Effect of Aqueous and Methanolic Bark, Leaf, and Flower Extracts of CF on Glucose Utilization in the RatHemidiaphragm Assay In Vitro. Albino rats of either sex were maintained on a standard pellet diet and water ad libitum and fasted overnight. The animals were sacrificed by decapitation and diaphragms were taken out quickly avoiding trauma and divided into two halves. The hemidiaphragms were then rinsed in cold Tyrode solution (without glucose) to remove any blood clots and were placed in a small conical flasks containing $2 \mathrm{~mL}$ Tyrode solution with $2000 \mathrm{mg} / \mathrm{L}$ glucose and incubated for $30 \mathrm{~min}$ at $37^{\circ} \mathrm{C}$ in an atmosphere of $95 \% \mathrm{O}_{2}+5 \% \mathrm{CO}_{2}$ with shaking at 140 cycles per min. Four sets of experiments were performed [22]. The animals were killed by decapitation and diaphragms were exposed to group I: tyrode solution with glucose $(2000 \mathrm{mg} / \mathrm{L})$ only and served as control. Group II: tyrode solution with glucose $\left(2000 \mathrm{mgL}^{-1}\right)+$ insulin $(0.25 \mathrm{IU} / \mathrm{mL})$. Group III: tyrode solution with glucose $\left(2000 \mathrm{mgL}^{-1}\right)$ bark methanol extract of $C F(25 \mathrm{mg} / \mathrm{mL})$. Group IV: tyrode solution with glucose $\left(2000 \mathrm{mgL}^{-1}\right)+$ insulin $\left(0.25 \mathrm{IUmL}^{-1}\right)+$ bark methanol extract of $C F\left(25 \mathrm{mgmL}^{-1}\right)$. Group V: tyrode 
TABLE 5: Effect of methanolic and aqueous bark, leaf, and flower extracts of Cassia fistula on serum Lipid profile in diabetic rats.

\begin{tabular}{lcccc}
\hline Group & TC $(\mathrm{mg} / \mathrm{dL})$ & TG $(\mathrm{mg} / \mathrm{dL})$ & HDL-C $(\mathrm{mg} / \mathrm{dL})$ & Non-HDL-C $(\mathrm{mg} / \mathrm{dL})$ \\
\hline Normal control & $59.96 \pm 1.84$ & $81.23 \pm 4.15$ & $32.2 \pm 1.4$ & $27.7 \pm 3.04$ \\
Diabetic control & $108.7 \pm 3.91$ & $170.1 \pm 3.60$ & $22.3 \pm 0.7$ & $86.4 \pm 4.20$ \\
Glibenclamide $(2.5 \mathrm{mg} / \mathrm{kg})$ & $67.74 \pm 3.34^{\mathrm{c}}$ & $84.03 \pm 2.20^{\mathrm{c}}$ & $29.9 \pm 1.1^{\mathrm{c}}$ & $37.9 \pm 3.07^{\mathrm{c}}$ \\
BME $250 \mathrm{mg} / \mathrm{kg}$ & $84.54 \pm 6.47^{\mathrm{c}}$ & $131 \pm 2.92^{\mathrm{c}}$ & $26.8 \pm 1.1$ & $58.2 \pm 6.22^{\mathrm{c}}$ \\
BAE $250 \mathrm{mg} / \mathrm{kg}$ & $96.16 \pm 2.60$ & $158.6 \pm 2.94$ & $24.9 \pm 0.5$ & $71.3 \pm 2.15^{\mathrm{a}}$ \\
BME $500 \mathrm{mg} / \mathrm{kg}$ & $74.32 \pm 2.34^{\mathrm{c}}$ & $90.41 \pm 3.07^{\mathrm{c}}$ & $28.3 \pm 0.8^{\mathrm{b}}$ & $46 \pm 2.35^{\mathrm{c}}$ \\
BAE $500 \mathrm{mg} / \mathrm{kg}$ & $90.24 \pm 1.61^{\mathrm{b}}$ & $156.4 \pm 3.19^{\mathrm{a}}$ & $25.8 \pm 1.4$ & $64.5 \pm 2.84^{\mathrm{c}}$ \\
LME $250 \mathrm{mg} / \mathrm{kg}$ & $94.45 \pm 2.46^{\mathrm{a}}$ & $157.3 \pm 1.81^{\mathrm{a}}$ & $24.7 \pm 1.1$ & $69.8 \pm 2.53^{\mathrm{a}}$ \\
LAE $250 \mathrm{mg} / \mathrm{kg}$ & $101.4 \pm 3.36$ & $160.2 \pm 3.33$ & $24.1 \pm 1.1$ & $77.3 \pm 4.13$ \\
LME $500 \mathrm{mg} / \mathrm{kg}$ & $78.25 \pm 3.40^{\mathrm{c}}$ & $96.13 \pm 2.51^{\mathrm{c}}$ & $27.2 \pm 0.9^{\mathrm{a}}$ & $51 \pm 3.50^{\mathrm{c}}$ \\
LAE $500 \mathrm{mg} / \mathrm{kg}$ & $98.74 \pm 3.11$ & $159.2 \pm 2.3$ & $25.2 \pm 1.6$ & $73.5 \pm 2.23$ \\
FME $250 \mathrm{mg} / \mathrm{kg}$ & $101.8 \pm 4.26$ & $160 \pm 3.34$ & $24.4 \pm 1.2$ & $77.3 \pm 5.05$ \\
FAE $250 \mathrm{mg} / \mathrm{kg}$ & $103.5 \pm 2.59$ & $161.9 \pm 1.90$ & $23.6 \pm 0.6$ & $80 \pm 2.15$ \\
FME $500 \mathrm{mg} / \mathrm{kg}$ & $97.29 \pm 3.36$ & $153.9 \pm 3.86^{\mathrm{b}}$ & $26.2 \pm 1.5$ & $71 \pm 3.74^{\mathrm{a}}$ \\
FAE $500 \mathrm{mg} / \mathrm{kg}$ & $100.5 \pm 3.77$ & $160.4 \pm 2.99$ & $24.9 \pm 1.3$ & $75.6 \pm 3.29$ \\
\hline
\end{tabular}

Values are mean $\pm \operatorname{SEM}(n=6)$.

$P$ value: ${ }^{\mathrm{a}}<0.05,{ }^{\mathrm{b}}<0.01,{ }^{\mathrm{c}}<0.001$ as compared with diabetic control group (by one-way ANOVA followed by Dunnett's multiple comparison test).

TABLE 6: Effect of methanolic and aqueous bark, leaf, and flower extracts of Cassia fistula on serum hepatic enzymes in diabetic rats.

\begin{tabular}{lccc}
\hline Group & AST (IU) & ALT (IU) & ALP (IU) \\
\hline Normal control & $99.25 \pm 5.28$ & $30.05 \pm 1.35$ & $74.6 \pm 3.53$ \\
Diabetic control & $128.4 \pm 4.52$ & $44.23 \pm 1.70$ & $132.8 \pm 2.69$ \\
Glibenclamide $(2.5 \mathrm{mg} / \mathrm{kg})$ & $96.82 \pm 2.66^{\mathrm{c}}$ & $34.11 \pm 2.31^{\mathrm{b}}$ & $80.68 \pm 4.16^{\mathrm{c}}$ \\
BME $250 \mathrm{mg} / \mathrm{kg}$ & $110.1 \pm 4.86$ & $37.6 \pm 3.17$ & $94.53 \pm 2.74^{\mathrm{c}}$ \\
BAE $250 \mathrm{mg} / \mathrm{kg}$ & $119.5 \pm 5.84$ & $38.25 \pm 2.62$ & $112.6 \pm 3.17^{\mathrm{b}}$ \\
BME $500 \mathrm{mg} / \mathrm{kg}$ & $100.8 \pm 3.61^{\mathrm{b}}$ & $34.56 \pm 1.26^{\mathrm{a}}$ & $85.43 \pm 2.93^{\mathrm{c}}$ \\
BAE $500 \mathrm{mg} / \mathrm{kg}$ & $119.8 \pm 5.84$ & $37.18 \pm 2.50$ & $96.25 \pm 3.34^{\mathrm{c}}$ \\
LME $250 \mathrm{mg} / \mathrm{kg}$ & $122.9 \pm 5.93$ & $38.79 \pm 1.54$ & $100.1 \pm 4.05^{\mathrm{c}}$ \\
LAE $250 \mathrm{mg} / \mathrm{kg}$ & $122.1 \pm 5.27$ & $40.53 \pm 1.25$ & $123.1 \pm 3.15$ \\
LME $500 \mathrm{mg} / \mathrm{kg}$ & $117.5 \pm 5.84$ & $35.85 \pm 2.54^{\mathrm{a}}$ & $89.27 \pm 3.03^{\mathrm{c}}$ \\
LAE $500 \mathrm{mg} / \mathrm{kg}$ & $121.1 \pm 4.18$ & $39.22 \pm 1.49$ & $118.1 \pm 2.79^{\mathrm{a}}$ \\
FME $250 \mathrm{mg} / \mathrm{kg}$ & $124 \pm 4.87$ & $39.14 \pm 2.62$ & $125.7 \pm 3.57$ \\
FAE $250 \mathrm{mg} / \mathrm{kg}$ & $124.3 \pm 4.79$ & $40.7 \pm 1.27$ & $126.4 \pm 2.98$ \\
FME $500 \mathrm{mg} / \mathrm{kg}$ & $120.4 \pm 5.39$ & $38.13 \pm 1.40$ & $108.4 \pm 5.32^{\mathrm{c}}$ \\
FAE $500 \mathrm{mg} / \mathrm{kg}$ & $122.5 \pm 5.84$ & $39.52 \pm 1.13$ & $122.9 \pm 3.38$ \\
\hline
\end{tabular}

Values are mean $\pm \operatorname{SEM}(n=6)$.

$P$ value: ${ }^{\mathrm{a}}<0.05,{ }^{\mathrm{b}}<0.01,{ }^{\mathrm{c}}<0.001$ as compared with diabetic control group (by one-way ANOVA followed by Dunnett's multiple comparison test).

solution with glucose $\left(2000 \mathrm{mgL}^{-1}\right)$ leaf methanol extract of CF $\left(25 \mathrm{mgmL}^{-1}\right)$. Group VI: tyrode solution with glucose $\left(2000 \mathrm{mgL}^{-1}\right)+$ insulin $\left(0.25 \mathrm{IUmL}^{-1}\right)+$ leaf methanol extract of CF (25 $\left.\mathrm{mgmL}^{-1}\right)$. Group VII: tyrode solution with glucose $\left(2000 \mathrm{mgL}^{-1}\right)$ flower methanol extract of CF $\left(25 \mathrm{mgmL}^{-1}\right)$. Group VIII: tyrode solution with glucose $\left(2000 \mathrm{mgL}^{-1}\right)+$ insulin $\left(0.25 \mathrm{IUmL}^{-1}\right)+$ flower methanol extract of $C F$ $\left(25 \mathrm{mgmL}^{-1}\right)$. Following incubation, the hemidiaphragms were taken out and weighed. The glucose content of the incubated medium was measured by GOD/POD, enzymatic method. Glucose uptake was calculated as the difference between the initial and final glucose content in the incubation medium.
2.10. Statistical Analysis. Statistical analysis was performed using Graph Pad Prism software package Version 5.0. The values were analyzed by one-way analysis of variance (ANOVA) followed by Dunnett's multiple comparison test.

\section{Results}

3.1. Phytochemical Evaluation of Extracts. The detailed studies of plant constituents for various extracts have been depicted in Table 1. Bark extracts show the presence of alkaloids, polyphenols, tannins, and some steroidal compounds whereas leaf extracts show the presence of high amount of glycosides and flavonoids. Similarly the flower and pods extracts show the presence of glycoside, alkaloids, 
TABLE 7: Effect of methanolic bark, leaf and, flower extract of Cassia fistula on glucose uptake by isolated rat hemidiaphragm in vitro assay on normal rats.

\begin{tabular}{|c|c|c|}
\hline Group & Incubation medium & $\begin{array}{l}\text { Glucose up take } \\
(\mathrm{mg} / \mathrm{g} \text { per } 30 \mathrm{~min})\end{array}$ \\
\hline 1 & Tyrode solution with glucose $(2000 \mathrm{mg} / \mathrm{L})$ control group & $4.83 \pm 0.32$ \\
\hline 2 & Tyrode solution with glucose $(2000 \mathrm{mg} / \mathrm{L})+$ insulin $(0.25 \mathrm{IU} / \mathrm{mL})$ & $8.73 \pm 0.4^{\mathrm{b}}$ \\
\hline 3 & Tyrode solution with glucose $(2000 \mathrm{mg} / \mathrm{L})+$ bark methanolic extract of C. fistula (25 mg/mL) & $6.15 \pm 0.21^{\mathrm{a}}$ \\
\hline 4 & $\begin{array}{l}\text { Tyrode solution with glucose }(2000 \mathrm{mg} / \mathrm{L})+\text { insulin }(0.25 \mathrm{IU} / \mathrm{mL})+\text { bark methanolic extract of } C \text {. fistula } \\
(25 \mathrm{mg} / \mathrm{mL})\end{array}$ & $13.66 \pm 0.21^{\mathrm{b}}$ \\
\hline 5 & Tyrode solution with glucose $(2000 \mathrm{mg} / \mathrm{L})+$ leaf methanolic extract of C. fistula $(25 \mathrm{mg} / \mathrm{mL})$ & $5.64 \pm 0.33$ \\
\hline 6 & $\begin{array}{l}\text { Tyrode solution with glucose }(2000 \mathrm{mg} / \mathrm{L})+\text { insulin }(0.25 \mathrm{IU} / \mathrm{mL})+\text { leaf methanolic extract of C. fistula } \\
(25 \mathrm{mg} / \mathrm{mL})\end{array}$ & $11.69 \pm 0.42^{\mathrm{b}}$ \\
\hline 7 & Tyrode solution with glucose $(2000 \mathrm{mg} / \mathrm{L})+$ flower methanolic extract of $C$. fistula $(25 \mathrm{mg} / \mathrm{mL})$ & $5.14 \pm 0.24$ \\
\hline 8 & $\begin{array}{l}\text { Tyrode solution with glucose }(2000 \mathrm{mg} / \mathrm{L})+\text { insulin }(0.25 \mathrm{IU} / \mathrm{mL})+\text { flower methanolic extract of } C \text {. fistula } \\
(25 \mathrm{mg} / \mathrm{mL})\end{array}$ & $9.20 \pm 0.13^{\mathrm{b}}$ \\
\hline
\end{tabular}

Values are mean $\pm \operatorname{SEM}(n=4)$.

$P$ values: ${ }^{\mathrm{a}}<0.01,{ }^{\mathrm{b}}<0.001$, as compared with control group (by one-way ANOVA followed by Dunnett's multiple comparison test).

flavonoids, some phenolic compounds, and along with all these constituents some resinous matters, respectively.

3.2. Acute Toxicity Study. The acute toxicity studies showed that the oral administration of the extracts did not cause death in the highest dose of $5 \mathrm{~g} \mathrm{~kg}^{-1}$ bw. The behavioral, neurological, and autonomic responses of the treated rats were all normal indicating it to be safe.

3.3. Evaluation of the Hypoglycemic Effects in Normoglycemic Rats. The hypoglycemic effects of the various extracts were evaluated in the fasting normoglycemic animals by administering either 250 or $500 \mathrm{mgkg}^{-1}$ (corresponding to $1 / 10$ th and $1 / 20$ th of the maximum tested dose) and estimating the blood glucose levels at $1,2,4$, and $8 \mathrm{~h}$ after treatment. The results showed that only BME $500 \mathrm{mgkg}^{-1}$ had shown significant hypoglycemic effect at $2 \mathrm{~h}(P<0.05), 4 \mathrm{~h}(P<0.01)$ and $8 \mathrm{~h}(P<0.01)$ followed by LME $500 \mathrm{mg} / \mathrm{kg}$ which has shown hypoglycemic effect starting from the 4th $\mathrm{h}(P<0.05)$ to the 8th $\mathrm{h}(P<0.01)$, as shown in Table 2 . However, the hypoglycemic effects of both these extracts were not as effective as glibenclamide which has shown significant hypoglycemic effect starting from the 2 nd $h$ to the 8 th $h$ $(P<0.001)$.

3.4. OGTT in Normal Rats. Figure 1 shows that both the doses of BME (250 and $500 \mathrm{mgkg}^{-1}$ ) have significantly reduced glucose AUC similar to that of standard drug glibenclamide $(P<0.001)$; whereas only higher dose of LME $500 \mathrm{mgkg}^{-1}$ has significantly reduced glucose AUC $(P<$ 0.05).

In both the above two experiments involving normal rats only bark and leaf methanolic extracts have shown significant hypoglycemic effect. There was also a trend towards decrease in glucose value of FME and aqueous extracts of bark and leaf whereas none of the extracts and doses of pods have shown

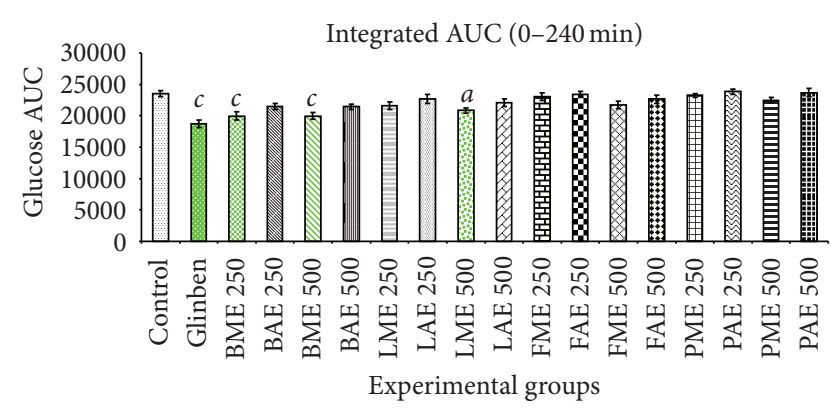

FIgURE 1: Effect of bark, leaf, flower, and pods aqueous and methanolic extracts of $C$. fistula on glucose AUC during OGTT. Bars represent mean values $\pm \operatorname{SEM}(n=6)$. $P$ values: $a<0.05, c<0.001$, as compared with normal control (by one-way ANOVA followed by Dunnetts multiple comparison test).

any hypoglycemic effect therefore they are not included in further studies.

3.5. Evaluation CF Extracts on Various Parameters in Type II DM Rats. Chronic administration of different extracts of CF has revealed the fact that BME at $500 \mathrm{mgkg}^{-1}$ has started exhibiting the antihyperglycemic effect from 7 th day onwards reaching the maximum beneficial effect on 21 st day. LME at $500 \mathrm{mgkg}^{-1}$ has started showing antihyperglycemic effect on 14th day onwards (Table 3). Antihyperglycemic effect exhibited by these two groups is similar to that of standard drug glibenclamide $(P<0.001)$. Similarly both BME and LME have significantly reduced the glycosylated haemoglobin level and increased the serum insulin level; however higher dose has shown better significance level similar to that of standard drug $(P<0.001)$ demonstrating the increased beta cell activity (Table 4 ). As chronic hyperglycemia is known to alter the levels of serum lipid profile by enhancing the levels of TC, non-HDL-C, and TG, with a concomitant decrease in the levels of HDL, we have observed 
increase in lipid profile level in DM control group whereas BME and LME $500 \mathrm{mgkg}^{-1}$ have shown improvement in lipid profile compared with DM control group (Table 5). Studies also have showed that the administration of BME and LME $500 \mathrm{mgkg}^{-1}$ caused a maximum reduction in the levels of liver damage enzymes AST, ALT, and ALP (Table 6). BME and LME $500 \mathrm{mgkg}^{-1}$ by decreasing the level of MDA have demonstrated the antioxidant potential of $C F$ (Figure 2). The result was supported by histopathological evidence, in which, compared to DM control, BME has shown both increase in number of islets in beta cells and islets size (Figure 3). Normal control (Figure 3(a)), diabetic control (Figure 3(b)), glibenclamide (Figure 3(c)), and bark methanolic extract $500 \mathrm{mg} / \mathrm{kg}$ b.wt. (Figure 3(d)) show mild reduction in beta cells and decrease in the number of islets.

3.6. Effect of Methanolic Bark, Leaf, and Flower Extract on Glucose Uptake in the Rat-Hemidiaphragm Assay In Vitro. The effects of the methanolic extracts of bark, leaf, and flowers on the glucose uptake by isolated rat hemidiaphragm are shown in Table 7. In the absence of insulin only BME $500 \mathrm{mgkg}^{-1}$ has significantly enhanced the glucose uptake $(P<0.05)$. Furthermore all three extracts were observed to be effective in enhancing the uptake of glucose in the presence of insulin significantly $(P<0.001)$ and were found to be more effective than insulin alone or the extracts alone.

\section{Discussion}

NIDDM is recognized to be a common and serious metabolic disorder throughout the world. Although, oral hypoglycemic agents/insulin are the mainstay of treatment of DM and are effective in controlling hyperglycemia, they have prominent side effects and fail to significantly alter the course DM complications [23]. The management efforts of hyperglycemia and the associated complications are labor intensive and challenging to both patients and the physicians. Furthermore, the economic burden associated with DM is severe to both the patient and the society [24].

Medicinal plants used in the various alternative and complementary systems of medicine are known to play an important role in the management of DM especially in developing countries where primary care facilities are compromised. In the present study, BME and LME at $500 \mathrm{mgkg}^{-1}$ have exhibited significant hypoglycemic property in normoglycemic rats. Similarly chronic administration of methanolic extracts of bark and leaf at $500 \mathrm{mgkg}^{-1}$ for 21 days significantly reduced glucose concentration in STZ + nicotinamide-induced diabetic rats. Both these groups have showed a comparable activity with glibenclamide-treated groups $(P<0.001)$ which is a standard antidiabetic drug that stimulates insulin secretion from beta cells of islets of Langerhans. Therefore the present study result indicates insulin stimulating property of the extract. The result also satisfies the earlier reports revealed by the researchers $[25$, 26]. It is also important to note that the typical characteristic of diabetes is the increase of serum glycosylated protein such as glycosylated hemoglobin (HbA1C), which is a parameter

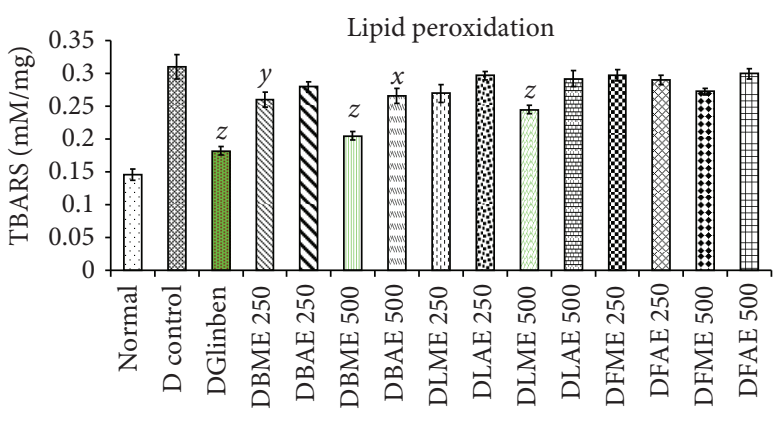

Experimental groups

FIGURE 2: Effect of on TBARS formation in rats under diabetes condition treated with bark, leaf, and flower aqueous and methanolic extracts of C. fistula. Bars represent mean values \pm SEM $(n=6) . P$ values: $x<0.05, z<0.001$, as compared with diabetic control (by one-way ANOVA followed by Dunnetts multiple comparison test).

for glycemic control where glucose or other reducing sugars react with the amino residues of proteins to form Amadori products-HbA1C. Animals treated with $500 \mathrm{mgkg}^{-1}$ of BME and LME have significantly decreased the HbAlC level which could be due to an improvement in insulin secretion from remnant pancreatic beta cells in diabetic rats [27]. Further the extract treated cohorts were observed to have shown statistically significant increase in serum insulin compared to DM controls. Histopathological observations also revealed that when compared to the DM control the cohorts receiving the extract had adequate number of islets and beta cells and less pyknotic nuclei and dark nuclei. In milieu of all these observations it can be hypothesized that the methanolic extract of both leaf and bark brings about its antihyperglycemic action by possibly potentiating secretion of insulin from $\beta$-cell of islets.

Insulin resistance is a major concern in the etiology of type II DM. Earlier literature revealed catechin could be developed into potential oral hypoglycemic drug because it possesses a potential agonist characteristic that is capable of activating insulin receptor and peroxisome proliferatoractivated receptor gamma [28]. We can conclude that the estimation of glucose content in rat hemidiaphragm model indicated that BME $500 \mathrm{mgkg}^{-1}$ alone has increased the glucose uptake even in the absence of insulin suggesting its hypoglycemic potential. However, in the presence of insulin, the methanolic extracts of the bark, leaves, and flowers were also effective. It was reported that Cassia fistula (L) flower extract also has antioxidant defense in streptozotocininduced diabetic rats [29] which was correlated with our study. The best effects were observed for the bark followed by leaves and flower and were better than insulin alone. The in vitro study of glucose utilization by isolated rat hemidiaphragm proposes that these extracts in combination with insulin potentiate its activity and enhance the utilization of glucose thereby being effective as an antidiabetic agent in type II DM.

In association to the chronic hyperglycemia, it has been known that hyperlipidemia and oxidative stress are 


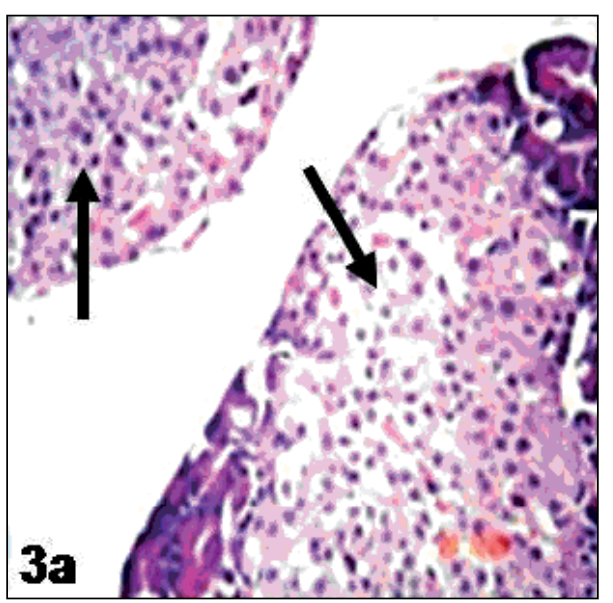

(a)

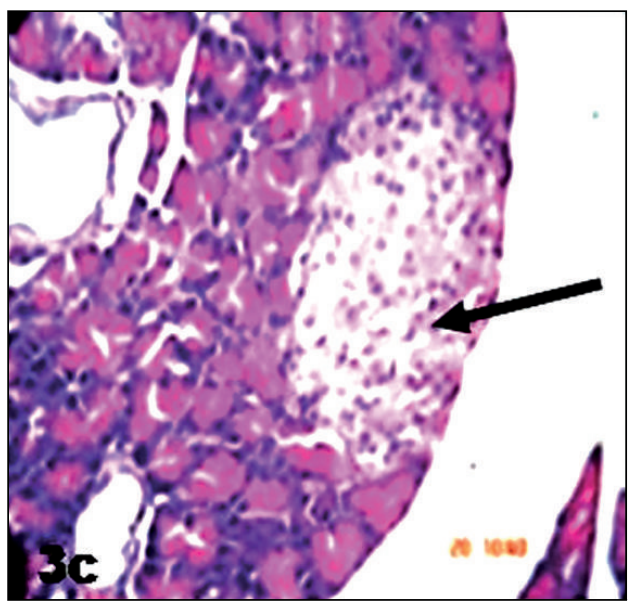

(c)

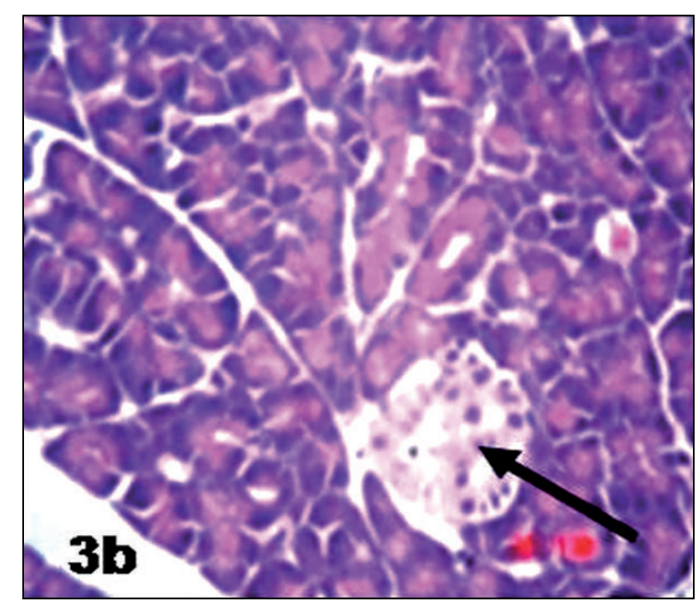

(b)

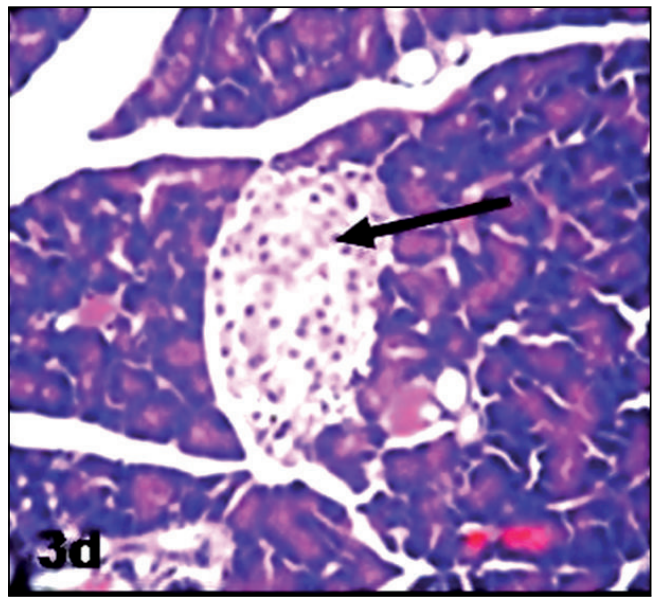

(d)

FIGURE 3: Histopathological features of the pancreases in the different cohorts.

pronounced in DM [30-32]. An atherogenic lipid profile characterized by elevated TGs and low levels of HDL-C are important contributors to insulin resistance and a risk factor for cardiovascular complications leading to $65 \%$ of death in patients with type II DM. Therefore an ideal anti-diabetic drug should have anti-hyperlipidemic effect in addition to antihyperglycemic activity. In the present study a marked increase in serum TC and TGs levels was observed in DM rats, and this observation was in agreement to earlier observations $[33,34]$. Administration of the various extracts and glibenclamide reduced the levels of serum TC and TG and increased the levels of HDL-C. The best effects were observed with the $500 \mathrm{mgkg}^{-1}$ of the BME and LME. Similar results have been explained earlier by Nirmala et al. [35]. They have reported that effect of hexane extract of Cassia fistula barks on blood glucose and lipid profile in streptozotocin diabetic rats. Thus, it is reasonable to conclude that methanolic extracts of bark and leaf of $C F$ could modulate blood lipid abnormalities in addition to antidiabetic activity. The similar report was revealed by Pitchai and Manikkam [28].

$\mathrm{DM}$ is one of the pathological processes known to be related to an unbalanced production of ROS, such as hydroxyl radicals $\left(\mathrm{HO}^{\bullet}\right)$, superoxide anions $\left(\mathrm{O}_{2}^{-\bullet}\right)$, and $\mathrm{H}_{2} \mathrm{O}_{2}$. Therefore, cells must be protected from this oxidative injury by antioxidant enzymes [36]. Free radicals and oxidative stress have long been implicated in eliciting complications of the DM condition. DM causes hypercholesterolemia. Hypercholesterolemia in turn is responsible for oxidative stress. It was reported that hypercholesterolaemia leads to increased production of OFR which exert their cytotoxic effect by causing LPO [37]. Its also known that LDL as such is not atherogenic it is the oxidized LDL which is atherogenic. Enhanced oxidative stress may depress the antioxidant defenses leading to exaggerated level of oxidized LDL and increased level of LPO. In the present study BME and LME $500 \mathrm{mgkg}^{-1}$ have decreased LPO more significantly thereby exhibited the antioxidant potential of $C F$.

DM is multifactorial in its pathogenesis and loss of insulin effect leads to glycogenolysis and ketogenesis, which then cumulatively lead to abnormalities in the liver function [38]. Elevation of transaminases three times the upper limits of ALT and AST enzymes indicates the liver damage induced by DM as also reported by Prince et al [39]. These observations were also replicated in our study in the DM cohorts. 
Administering the extracts especially BME $500 \mathrm{mgkg}^{-1}$ has produced significant beneficial effect in all the liver marker enzymes tested indicating their hepatoprotective effects.

The first probable anti-diabetic mechanism of action of the $C F$ plant extract could be linked to increase in plasma insulin. Though the exact mechanism of action of the extract is not known, it could be due to increased pancreatic secretion of insulin from existing beta cells as shown in the biochemical tests, namely, glucose, HbA1C, and insulin. Second likely mechanism is increased binding of insulin to insulin receptor thereby increasing the uptake of glucose by $C F$ extracts as demonstrated in rat hemidiaphragm experiment. Third mechanism could be antioxidant property as exerted by decreasing the lipid peroxidation in the present study. Previous studies have conclusively shown that the phytochemicals epicatechin, flavanoids, proanthocyanidins, and kaempferol possess hypoglycemic effects. It is well known that certain flavonoids exhibit hypoglycemic activity and pancreas beta cell regeneration ability. Thus the significant anti-diabetic effect of BME and LME may be due to the presence of more than one antihyperglycemic principle and their synergic properties [40, 41]. It was also observed that among the extracts tested the methanolic extract of the bark and leaves was the most effective. Our observations are in agreement to that of Daisy et al. [42], who have also observed that the methanol extract of Tinospora cordifolia stem was effective in reducing the blood glucose levels in STZ-induced type I $\mathrm{DM}$ in rats. Together both these observations indicate that the methanolic extract is effective in inducing hypoglycemic effects in both type I and II DM. Therefore all these observations clearly validate our experimental observations.

\section{Conclusion}

Data accrued from the present study clearly indicate that the methanolic extract of the bark and leaves at $500 \mathrm{mgkg}^{-1}$ dose exhibited significant antihyperglycemic and antilipidemic activity than at low dose $\left(250 \mathrm{mgkg}^{-1}\right)$ in the STZnictotinamide-induced DM rats. These extracts also showed improvement in parameters glycosylated hemoglobin and insulin profile as well as regeneration of beta cells of pancreas and so might be of value in DM treatment. Therefore, further investigation is necessary to determine the exact phytoconstituent(s) responsible for anti-DM effect.

\section{References}

[1] K. A. Wadkar, C. S. Magdum, S. S. Patil, and N. S. Naikwade, "Anti-diabetic potential and indian medicinal plants," Journal of Herbal Medicine and Toxicology, vol. 2, no. 1, pp. 45-50, 2008.

[2] J. K. Grover, S. Yadav, and V. Vats, "Medicinal plants of India with anti-diabetic potential," Journal of Ethnopharmacology, vol. 81, no. 1, pp. 81-100, 2002.

[3] P. Daisya, K. Balasubramanian, M. Rajalakshmi, J. Elizaa, and J. Selvaraj, "Insulin mimetic impact of Catechin isolated from Cassia fistula on the glucose oxidation and molecular mechanisms of glucose uptake on Streptozotocin-induced diabetic Wistar rats," Phytomedicine, vol. 17, no. 1, pp. 28-36, 2010.
[4] K. R. Kritikar and B. A. Basu, Indian Medicinal Plants, Periodical Experts Book Agency, New Delhi, India, 2nd edition, 1991.

[5] K. Vasudevan, S. Manoharan, K. Panjamurthy, L. Vellaichamy, and A. Chellammal, "Evaluation of antihyperglycemic effect of Cassia fistula (linn.) leaves in streptozotocin induced diabetic rats," Electronic Journal of Pharmacology and Therapy, vol. 1, pp. 57-60, 2008.

[6] R. Perumal, S. Samy, S. Ignacimuthu, and A. Sen, "Screening of 34 Indian medicinal plants for antibacterial properties," Journal of Ethnopharmacology, vol. 62, no. 2, pp. 173-181, 1998.

[7] M. Gupta, U. K. Mazumder, N. Rath, and D. K. Mukhopadhyay, "Antitumor activity of methanolic extract of Cassia fistula L. seed against Ehrlich Ascites Carcinoma," Journal of Ethnopharmacology, vol. 72, no. 1-2, pp. 151-156, 2000.

[8] R. Yadav and G. C. Jain, "Antifertility effect of aqueous extract of seeds of Cassia fistula in female rats," Advances in Contraception, vol. 15, no. 4, pp. 293-301, 1999.

[9] H. Kuo, P. H. Lee, and Y. S. Wein, "Four new compounds from the seeds of Cassia fistula," Journal of Natural Products, vol. 65, no. 8, pp. 1165-1167, 2002.

[10] P. Siddhuraju, P. S. Mohan, and K. Becker, "Studies on the antioxidant activity of Indian Laburnum (Cassia fistula L.): a preliminary assessment of crude extracts from stem bark, leaves, flowers and fruit pulp," Food Chemistry, vol. 79, no. 1, pp. 61-67, 2002.

[11] A. M. Esposito, A. Diaz, R. De Graia, I. De Tellor, and M. P. Gupta, "Evaluation of traditional medicine: effects of Cajanus cajan L. and Cassia fistula L. on carbohydrate metabolism in mice," Revista Médica de Panamá Journal, vol. 16, pp. 39-45, 1991.

[12] Organization for Economic Co-operation and Development (OECD), vol. 423, pp. 1-14, 2001.

[13] H. Varley, A. H. Gowenlock, and M. Bell, Practical Biochemistry, vol. 1, London, UK, 5th edition, 1976, Edited by: I. W. Heinemann.

[14] S. Bonner-Weir, "Morphological evidence for pancreatic polarity of $\beta$-cell within islets of Langerhans," Diabetes, vol. 37, no. 5, pp. 616-621, 1988.

[15] A. Shirwaikar, K. Rajendran, and C. Kumar, "Oral antidiabetic activity of Annona squamosa leaf alcohol extract in NIDDM rats," Pharmaceutical Biology, vol. 42, no. 1, pp. 30-35, 2004.

[16] K. L. Bairy, A. Sharma, and A. Shalini, "Evaluation of the hypoglycemic, hypolipidemic and hepatic glycogen raising effects of Syzygium malaccense upon streptozotocin induced diabetic rats," Journal of Natural Remedies, vol. 5, no. 1, pp. 46-51, 2005.

[17] T. K. Mayer and Z. R. Freedman, "Protein glycosylation in diabetes mellitus: a review of laboratory measurements and of their clinical utility," Clinica Chimica Acta, vol. 127, no. 2, pp. 147-184, 1983.

[18] H. V. Webster, A. J. Bone, K. A. Webster, and T. J. Wilkin, "Comparison of an enzyme-linked immunosorbent assay (ELISA) with a radioimmunoassay (RIA) for the measurement of rat insulin," Journal of Immunological Methods, vol. 134, no. 1, pp. 95-100, 1990.

[19] O. H. Lowry, N. J. Rosebrough, A. L. Farr, and R. J. Randall, "Protein measurement with the Folin phenol reagent," The Journal of Biological Chemistry, vol. 193, no. 1, pp. 265-275, 1951.

[20] H. Ohkawa, N. Ohishi, and K. Yagi, "Assay for lipid peroxides in animal tissues by thiobarbituric acid reaction," Analytical Biochemistry, vol. 95, no. 2, pp. 351-358, 1979. 
[21] H. Varley, Practical Clinical Biochemistry, CBS, Delhi, India, 1988, Edited by: H. Varley.

[22] M. C. Sabu and T. Subburaju, "Effect of Cassia auriculata Linn. on serum glucose level, glucose utilization by isolated rat hemidiaphragm," Journal of Ethnopharmacology, vol. 80, no. 23, pp. 203-206, 2002.

[23] H. P. Rang and M. M. Dale, Endocrine System Pharmacology, Longman Group, Essex, UK, 2nd edition, 1991.

[24] S. Van Dieren, J. W. Beulens, Y. T. van der Schouw, D. E. Grobbee, and B. Neal, "The global burden of diabetes and its complications: an emerging pandemic," European Journal of Cardiovascular Prevention \& Rehabilitation, vol. 17, supplement 1, pp. S3-S8, 2010.

[25] Z. I. Khan, B. Nahar, M. A. Jakaria, S. Rahman, M. H. Chowdhury, and M. Rahmatullah, "An evaluation of antihyperglycemic and antinociceptive effects of methanol extract of Cassia fistula 1. (Fabaceae) leaves in Swiss albino mice," Advances in Natural and Applied Sciences, vol. 4, no. 3, pp. 305-310, 2010.

[26] J. Edwin, S. B. Joshi, and D. C. Jain, "Biochemical study on the hypoglycemic effects of extract and fraction of barks of Cassia fistula Linn. in alloxan-induced diabetic rats," Indian Drugs, vol. 46, no. 7, pp. 54-60, 2009.

[27] H. M. Eshrat, "Effect of Coccinia indica (L.) and Abroma augusta (L.) on glycemia, lipid profile and on indicators of end-organ damage in streptozotocin induced diabetic rats," Indian Journal of Clinical Biochemistry, vol. 18, no. 2, pp. 54-63, 2003.

[28] D. Pitchai and R. Manikkam, "Hypoglycemic and insulin mimetic impact of catechin isolated from Cassia fistula: a substantiate in silico approach through docking analysis," Medicinal Chemistry Research. In press.

[29] K. A. Jeyanthi, "Beneficial effect of Cassia fistula (L) flower extract on antioxidant defense in streptozotocin induced diabetic rats," International Journal of Pharmacy and Pharmaceutical Sciences, vol. 4, no. 2, pp. 274-276, 2012.

[30] R. A. Defronzo, R. C. Bondonna, and E. Ferranini, "Pathogenesis of NIDDM: a balanced overview," Diabetes Care, vol. 15, no. 3, pp. 318-368, 1992.

[31] A. Chait and J. D. Brunzell, "Diabetes, lipids and atherosclerosis," in Diabetes Mellitus, D. LeRoith, S. I. Taylor, and J. M. Olefsky, Eds., pp. 467-469, Lippincott-Raven, Philadelphia, Pa, USA, 1996.

[32] L. Pari and M. Latha, "Effect of Cassia auriculata flowers on blood sugar levels, serum and tissue lipids in streptozotocin diabetic rats," Singapore Medical Journal, vol. 43, no. 12, pp. 617-621, 2002.

[33] K. G. M. M. Alberti, P. Zimmet, and R. A. DeFronzo, International Textbook of Diabetes Mellitus, John Wiley \& Sons, New York, NY, USA, 2nd edition, 1997.

[34] U.K. Prospective Diabetes Study Group, "U.K. Prospective Diabetes Study 27: plasma lipids and lipoproteins at diagnosis of NIDDM by age and sex," Diabetes Care, vol. 20, pp. 1683-1687, 1997.

[35] A. Nirmala, J. Eliza, M. Rajalakshmi, E. Priya, and P. Daisy, "Effect of hexane extract of Cassia fistula barks on blood glucose and lipid profile in Streptozotocin diabetic rats," International Journal of Pharmacology, vol. 4, no. 4, pp. 292-296, 2008.

[36] Canadian Diabetes Association and Clinical Practice Guidelines Expert Committee, "Dyslipidemia in adults with diabetes," Canadian Journal of Diabetes, vol. 30, pp. 230-240, 2006.
[37] B. M. Kochikuzhyli, K. Devi, and S. R. Fattepur, "Effect of saturated fatty acid-rich dietary vegetable oils on lipid profile, antioxidant enzymes and glucose tolerance in diabetic rats," Indian Journal of Pharmacology, vol. 42, no. 3, pp. 142-145, 2010.

[38] K. Prasad and J. Kalra, "Oxygen free radicals and hypercholesterolemic atherosclerosis: effect of vitamin E," American Heart Journal, vol. 125, no. 4, pp. 958-973, 1993.

[39] P. S. M. Prince, V. P. Menon, and L. Pari, "Effect of Syzigium cumini extracts on hepatic hexokinase and glucose-6-phosphatase in experimental diabetes," Phytotherapy Research, vol. 11, no. 7, pp. 529-531, 1997.

[40] S. Wolfram, D. Raederstorff, M. Preller et al., "Epigallocatechin gallate supplementation alleviates diabetes in rodents," Journal of Nutrition, vol. 136, no. 10, pp. 2512-2518, 2006.

[41] M. Shimada, K. Mochizuki, N. Sakurai, and T. Goda, "Dietary supplementation with epigallocatechin gallate elevates levels of circulating adiponectin in non-obese type-2 diabetic gotokakizaki rats," Bioscience, Biotechnology, and Biochemistry, vol. 71, no. 8, pp. 2079-2082, 2007.

[42] P. Daisy, M. Rajalakshmi, J. Eliza, C. E. Priya, and A. Nirmala, "Anti-diabetic properties of Tinospora cordifolia stem extracts on streptozotocin- induced diabetic rats," African Journal of Pharmacy and Pharmacology, vol. 3, no. 5, pp. 171-180, 2009. 

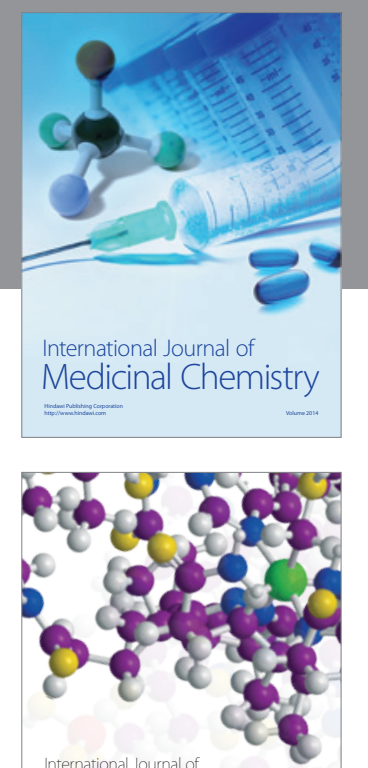

\section{Carbohydrate} Chemistry

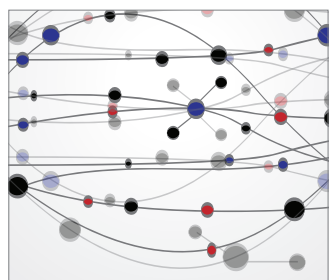

The Scientific World Journal
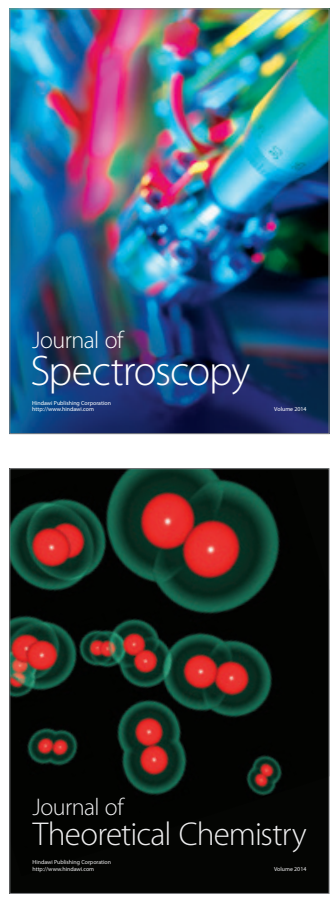
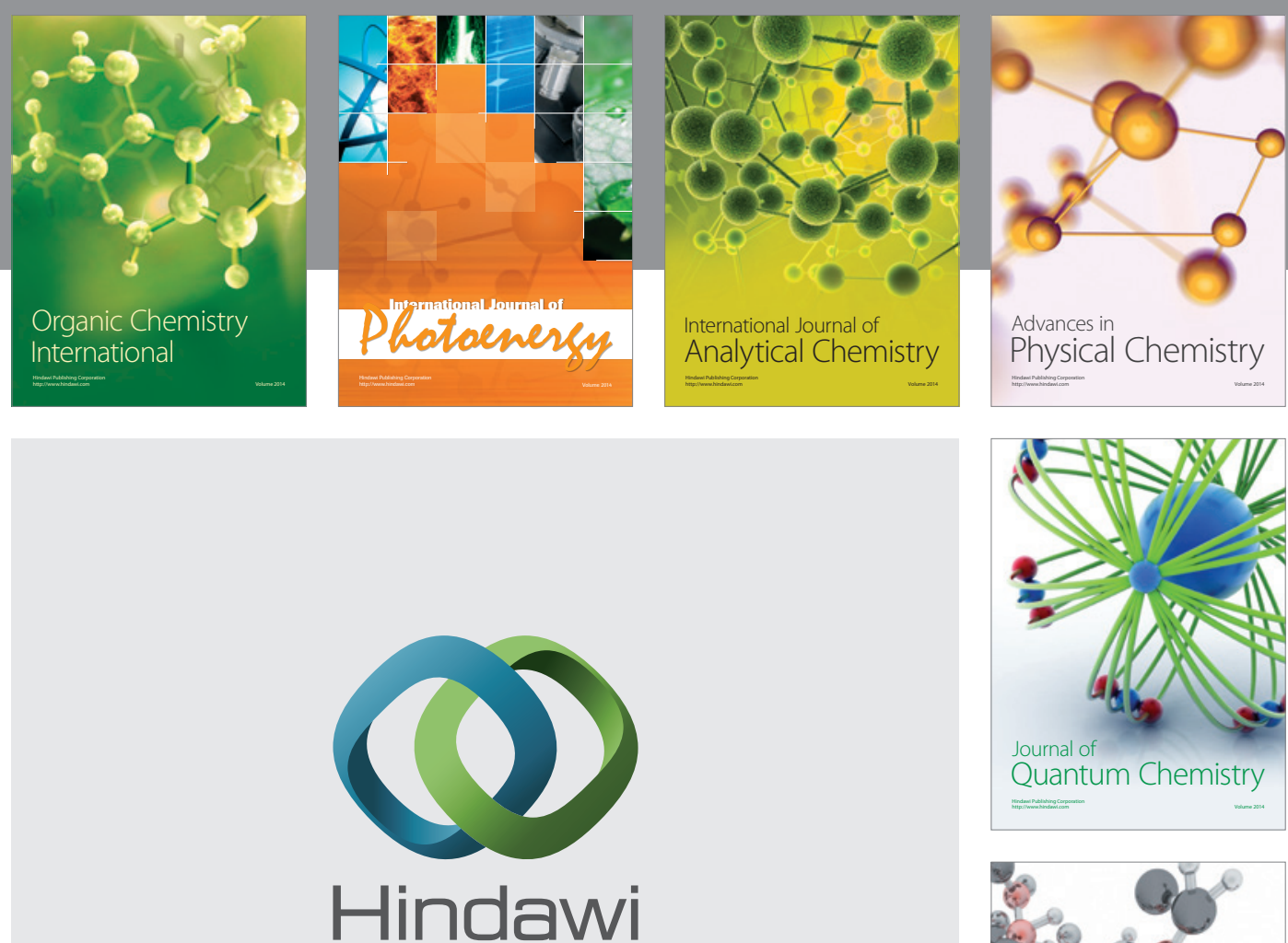

Submit your manuscripts at

http://www.hindawi.com

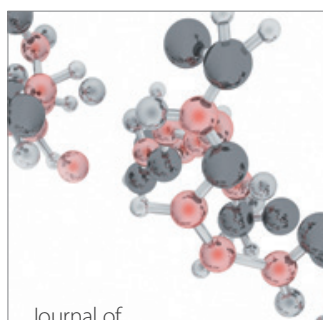

Analytical Methods

in Chemistry

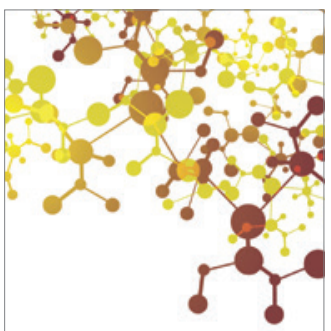

Journal of

Applied Chemistry

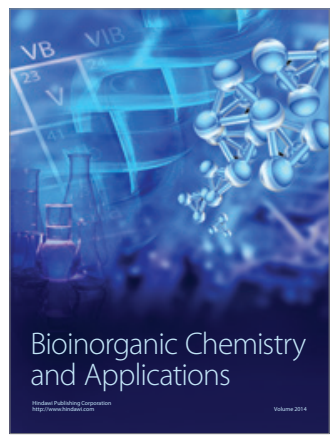

Inorganic Chemistry
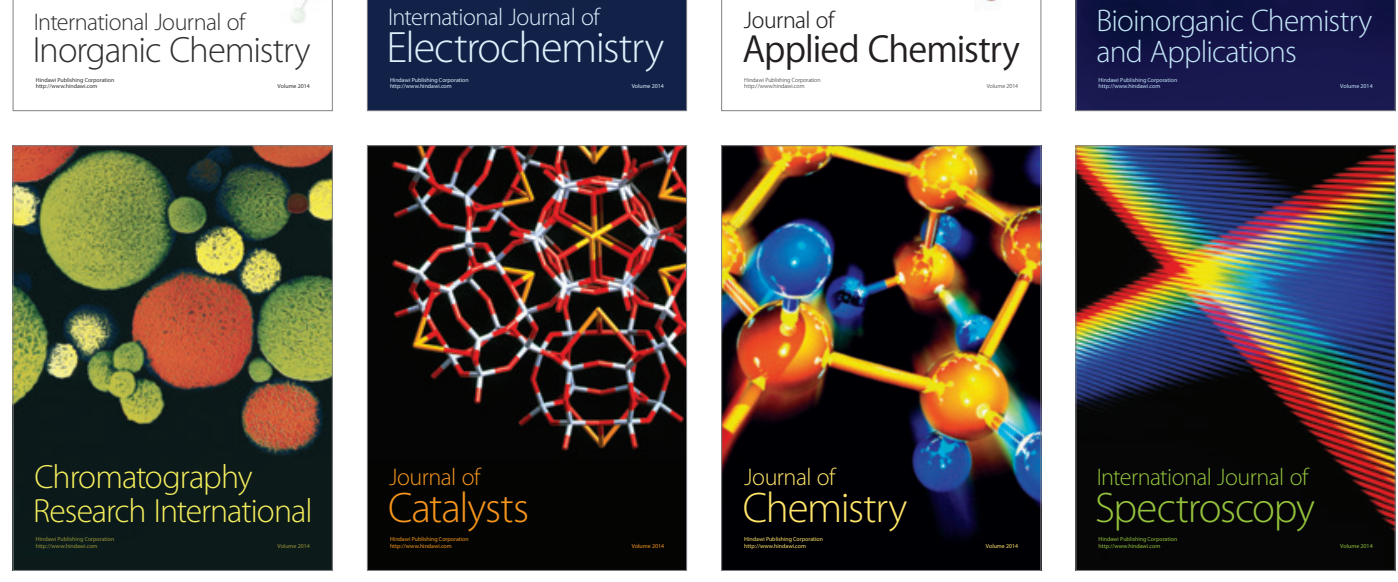